\title{
ARD
}

\section{Systemic levels of IL-23 are strongly associated with disease activity in rheumatoid arthritis but not spondyloarthritis}

Lode Melis, Bernard Vandooren, Elli Kruithof, et al.

Ann Rheum Dis 2010 69: 618-623 originally published online February 5, 2009

doi: 10.1136/ard.2009.107649

Updated information and services can be found at:

http://ard.bmj.com/content/69/3/618.full.html

\section{These include:}

References This article cites 45 articles, 20 of which can be accessed free at: http://ard.bmj.com/content/69/3/618.full.html\#ref-list-1

Email alerting Receive free email alerts when new articles cite this article. Sign up in the service box at the top right corner of the online article.

Notes

To order reprints of this article go to:

http://ard.bmj.com/cgi/reprintform

To subscribe to Annals of the Rheumatic Diseases go to:

http://ard.bmj.com/subscriptions 


\title{
Systemic levels of IL-23 are strongly associated with disease activity in rheumatoid arthritis but not spondyloarthritis
}

\author{
Lode Melis, ${ }^{1}$ Bernard Vandooren, ${ }^{1}$ Elli Kruithof, ${ }^{1}$ Peggy Jacques, ${ }^{1}$ Martine De Vos, ${ }^{2}$ \\ Herman Mielants, ${ }^{1}$ Gust Verbruggen, ${ }^{1}$ Filip De Keyser, ${ }^{1}$ Dirk Elewaut ${ }^{1}$
}

'Department of Rheumatology, Ghent University Hospital, Belgium

2Department of

Gastroenterology, Ghent University Hospital, Belgium

Correspondence to

Dr Dirk Elewaut, Laboratory

for Molecular Immunology and Inflammation, Department of Rheumatology, Ghent University Hospital, 0K12IB, De Pintelaan 185, 9000 Ghent, Belgium; dirk.elewaut@ugent.be

Accepted 28 January 2009

The first two authors contributed equally to this study.

\begin{abstract}
Objectives Th17 cells are an effector T-cell population that plays a role in chronic inflammatory conditions and is dependent on IL-23 for their survival and expansion. More recently, a genetic association was discovered between polymorphisms in the gene coding for the IL-23 receptor and spondyloarthritis. This study aimed to evaluate the role of Th17associated cytokines in spondyloarthritis pathogenesis by measuring their levels in the joints and circulation as well as correlating them with disease activity parameters.
\end{abstract}

Methods Paired synovial fluid (SF), serum and synovial biopsies were obtained from 30 non-PsA (psoriatic arthritis) spondyloarthritis, 22 PsA and 22 rheumatoid arthritis (RA) patients. IL-17, IL-23 and CCL20 were measured by ELISA in the SF and serum of patients and correlated with systemic and local parameters of disease activity.

Results Concentrations of CCL20, a major Th17attracting chemokine, tended to be higher in the joints of RA than in spondyloarthritis patients. Interestingly, levels of CCL2O were markedly higher in SF as opposed to serum. In addition, there was a remarkable association between the expression of the Th17 cytokine system and the presence of intimal lining layer hyperplasia in RA. Also in the serum, there was a tendency for higher IL-23 levels in $\mathrm{RA}$, which correlated strongly with disease activity parameters.

Conclusions Th17-related cytokines are expressed in joints of spondyloarthritis as well as RA patients. IL-23 levels, however, correlate with disease activity parameters in RA only. These results point towards a differential regulation of the Th17 cytokine system in spondyloarthritis compared with RA.

Spondyloarthritis is a chronic inflammatory disease that affects approximately $0.5 \%$ of the western population. The symptoms usually start in the third decade of life, and are primarily the result of the presence of inflammation in the spine (spondylitis) and joints (arthritis), sometimes together with inflammation of the eye (anterior uveitis), gut (ileitis or colitis) and skin (psoriasis). The aetiology of the disease is unknown, but family studies have shown that there is an important genetic contribution to the disease. ${ }^{1}$ Apart from HLA-B27, recent studies demonstrated that polymorphisms in the gene coding for the IL-23 receptor are also strongly linked to the development of spondyloarthritis. ${ }^{2}$

IL-17-producing $\mathrm{T}$ helper (Th17) cells are a recently discovered effector T-lymphocyte subset, ${ }^{3}$ which plays a critical role in several animal models of chronic inflammatory diseases, such as collagen-induced arthritis, ${ }^{4} \mathrm{~T}$-cell-mediated colitis ${ }^{5}$ and experimental uveitis. ${ }^{6}$

In contrast to other effector T-cell subsets, Th17 cells express the IL-23 receptor on their membrane and are dependent on this cytokine for their survival and expansion. ${ }^{7}$

In addition, Th17 cells, unlike other effector T-cell subsets, express the chemokine receptor, CCR6, on their membrane, ${ }^{8}$ which can be activated by its cognate ligand, CCL20. ${ }^{9}$ Interfering with IL-23R or CCR6 activation has been shown to be an effective treatment strategy in different animal models of arthritis. ${ }^{410}$ Th17 cells are also very likely to play an important role in human chronic inflammatory conditions, because polymorphisms in the IL-23 receptor are closely associated with the development of Crohn's disease ${ }^{11}$ as well as psoriasis. ${ }^{12}$ Furthermore, Th17 cells are enriched in the inflammatory lesions in both diseases, ${ }^{13}$ 14 and treatment of patients with anti-IL-23 p40, which blocks both IL-12 and IL-23, has a beneficial effect on the disease course in Crohn's disease ${ }^{15}$ and psoriasis. ${ }^{16}$

Considering the genetic association between IL-23 receptor polymorphisms and spondyloarthritis $^{2}$ as well as the established role of Th17 cells in spondyloarthritis-related inflammatory diseases, 4-61516 we wanted to assess the potential role of the Th17 cytokine system in spondyloarthritis joint inflammation. Therefore we measured the concentration of IL-17, IL-23 and CCL20 in the joints and serum of spondyloarthritis patients, compared it with rheumatoid arthritis (RA) patients and related it to local and systemic parameters of disease activity.

\section{PATIENTS AND METHODS \\ Patients}

The first study population consisted of paired samples of synovial fluid (SF), synovial biopsies and serum from 52 spondyloarthritis patients fulfilling the European Spondyloarthropathy Study Group classification criteria for spondyloarthritis ${ }^{17}$ and 22 RA patients fulfilling the American College of Rheumatology Classification criteria for RA. ${ }^{18}$ The spondyloarthritis cohort consisted of 22 patients with psoriatic arthritis (PsA) fulfilling in addition the CASPAR criteria ${ }^{19}$ and 30 patients with non-psoriatic arthritis spondyloarthritis (non-PsA SpA) (six ankylosing spondylitis (AS) patients, 22 undifferentiated spondyloarthritis 
(USpA) patients and two patients with reactive arthritis $(\operatorname{Re} A))$. SF and synovial biopsies were obtained by needle arthroscopy of the knee as previously described. ${ }^{20}$ All patients had a clinical joint effusion at the time of arthroscopy. In addition, serum samples were collected from eight healthy control (HC) subjects (mean age 27.63 years; SEM 1.15; six men and two women). SF and serum samples were stored at $-20^{\circ} \mathrm{C}$. Synovial biopsies were formalin fixed or snap frozen in liquid nitrogen.

The second study population consisted of 15 spondyloarthritis patients (seven with PsA and eight with non-PsA SpA (seven AS patients and one USpA patient)) with indications for TNF blockade treatment. From these patients, serum samples were collected before and after 12 weeks of treatment with infliximab ( $5 \mathrm{mg} / \mathrm{kg}$ at weeks 0,2 and 6).

Written informed consent was given by all the patients before inclusion in the study, as approved by the Ethics Committee of the Ghent University Hospital.

\section{Enzyme-linked immunosorbent assay}

Synovial fluid and serum IL-17 and CCL20 were measured with commercial sandwich ELISA following the manufacturer's instructions (DuoSet ELISA Development System; R\&D Systems, Abingdon, UK). For CCL20 measurements, the SF was diluted 20 -fold in $1 \%$ bovine serum albumin in phosphate buffered saline. IL-23 was measured by a commercial sandwich ELISA following the manufacturer's instructions (eBioscience, San Diego, California, USA). The assay consists of a capture antibody directed against the human IL-23 p19 subunit and a biotinylated detection antibody recognising the human IL-12/IL-23 p40 subunit.

\section{Histopathology and immunohistochemistry}

After fixation in $4 \%$ formaldehyde, the biopsies were embedded in paraffin and cut into $4 \mu \mathrm{m}$ sections. The procedure for histological and immunohistochemical analysis of the different markers was extensively described and validated previously. ${ }^{21}$ Briefly, paraffin sections were deparaffinised and either directly stained with haematoxylin and eosin for routine histology or processed for immunohistochemistry. T cells were detected with anti-CD3 (Clone UCHT1; Dako, Glostrup, Denmark) and B lymphocytes with anti-CD20 (Clone L26; Dako). After incubation with the primary antibody, the sections were sequentially incubated with a biotinylated second antibody, a streptavidin-horse radish peroxidase link, and finally with amino-ethyl-carbazole substrate as chromogen (Dako).

\section{Microscopic analysis}

The histopathological characteristics of the synovial membrane and the immunohistochemical stainings were assessed by semiquantitative scoring (0-3) by two independent observers, as extensively described and validated previously. ${ }^{21}$

The scores never differed by more than one score and the mean of both observers was used in the case of one-point discordance. The observers were blinded for diagnosis and the slides were evaluated in random order.

\section{Statistics}

All analyses were performed using SPSS software. Nonparametric data were analysed using the Kruskal-Wallis or the Mann-Whitney $U$ test for comparisons between groups. The paired Wilcoxon signed ranks test was used in case of paired non-parametric data.
Normally distributed data were analysed using the one-way analysis of variance, the independent-samples $t$ test and the paired-samples t test. Correlation coefficients were calculated with the Spearman correlation coefficient test.

\section{RESULTS}

We first evaluated whether the arthritis cohorts showed any differences in the degree of inflammatory activity at the time of sampling. The number of polymorphonuclear cells in the joint fluid and the degree of cellular infiltration of the synovial membrane were considered as local parameters of joint inflammation, whereas C-reactive protein (CRP) and erythrocyte sedimentation rate (ESR) levels were regarded as systemic parameters of inflammation. As shown in table 1 the degree of local as well as systemic inflammatory activity was not significantly different between the cohorts. This indicates that eventual differences in the levels of inflammatory mediators between the RA, non-PsA $\mathrm{SpA}$ and PsA cohorts would be the result of genuine diseasespecific traits rather than merely differences in the intensity of inflammation.

\section{CCL20 levels are elevated in the synovial fluid of non-PsA SpA, PsA and RA patients compared to serum}

We next measured steady-state SF levels of IL-17 and IL-23.

The concentration of IL-17 in the SF tended to be higher in nonPsA SpA patients compared with RA and PsA patients (non-PsA SpA mean 43.92 pg/ml; SEM 17.07 vs RA 29.41 pg/ml; SEM 10.03 vs PsA 31.68 pg/ml; SEM 16.81 ( $p=0.386))$. In contrast, the concentration of IL-23, the major Th17 driving cytokine, was similar in the joints of RA, non-PsA SpA and PsA patients ( $p=0.816$ ).

In contrast, the concentration of the Th17 attracting chemokine, CCL20, tended to be higher in RA patients than in non-PsA SpA and PsA patients (RA mean 2340.31 pg/ml; SEM 742.41 vs nonPsA SpA 876.34 pg/ml; SEM 390.88 vs PsA 1186.71 pg/ml; SEM $570.15(\mathrm{p}=0.079))$.

A true chemotactic role for CCL20 in attracting immune cells to the joints of arthritis patients was suggested by the fact that the concentration was strongly elevated in the SF in comparison to the serum in RA (mean 255.08-fold; SEM 59.33; $\mathrm{p}=0.001$ ), non-PsA SpA (mean 242.85-fold; SEM 95.11; p<0.001) and PsA (mean 170.99-fold; SEM 78.09; p<0.001) (figure 1).

\section{Synovial fluid CCL20 correlates with joint inflammation in spondyloarthritis and RA}

Considering the pathogenic role of the IL-23/IL-17 cytokine axis in driving joint inflammation in several arthritic mouse models, ${ }^{22-24}$ we evaluated if the presence of IL-23 or IL-17 protein in the joints of spondyloarthritis patients was related to features of joint inflammation. In contrast with previous reports of observations in airway inflammation ${ }^{25-27}$ we did not find a significant relationship between local IL-23 or IL-17 levels and SF polymorphonuclear count in RA, PsA or non-PsA SpA patients (table 2).

Remarkably, SF CCL20 levels correlated strongly with SF polymorphonuclear numbers in RA (r 0.498; p=0.021), PsA (r 0.639; $\mathrm{p}=0.006$ ) and non-PsA SpA (r 0.654; $\mathrm{p}=0.001)$.

On histopathological evaluation of the synovial tissue, SF IL-17 concentration was closely correlated with the degree of intimal lining layer hyperplasia in RA ( $\mathrm{r} 0.583$; $\mathrm{p}=0.009$ ), but not in spondyloarthritis patients.

This was also the case for SF IL-23 (r 0.657, $\mathrm{p}=0.002$ ) and SF CCL20 (r 0.463, p=0.046). Furthermore, SF CCL20 strongly correlated with global synovial cellular infiltration in RA patients ( $r$ 0.607; $\mathrm{p}=0.006$ ), but not in spondyloarthritis patients (table 2). 
Table 1 Demographic, clinical, biochemical and histopathological data of the patient cohorts

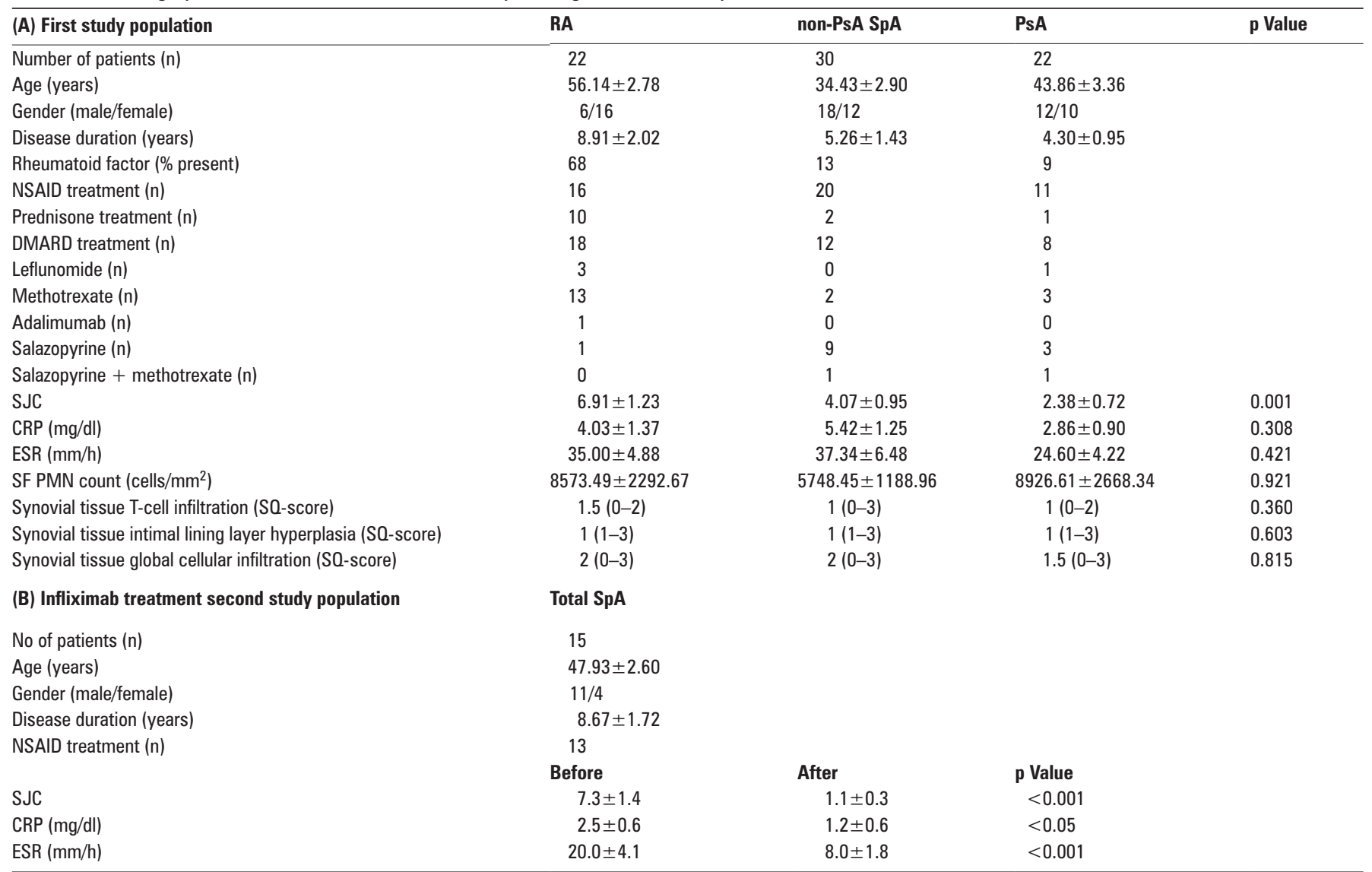

Quantitative data are represented as means \pm SEM, whereas semiquantitative scores (SQ-scores) are indicated as medians (ranges). Table (A) represents the data of the first study population, while table (B) shows the results for the infliximab serum second study population.

CRP, C-reactive protein; DMARD, disease-modifying antirheumatic drug; ESR, erythrocyte sedimentation rate; NSAID, non-steroidal anti-inflammatory drug; PMN, polymorphonuclear; PsA, psoriatic arthritis; RA, rheumatoid arthritis; SF, synovial fluid; SJC, swollen joint count; SpA, spondyloarthritis.
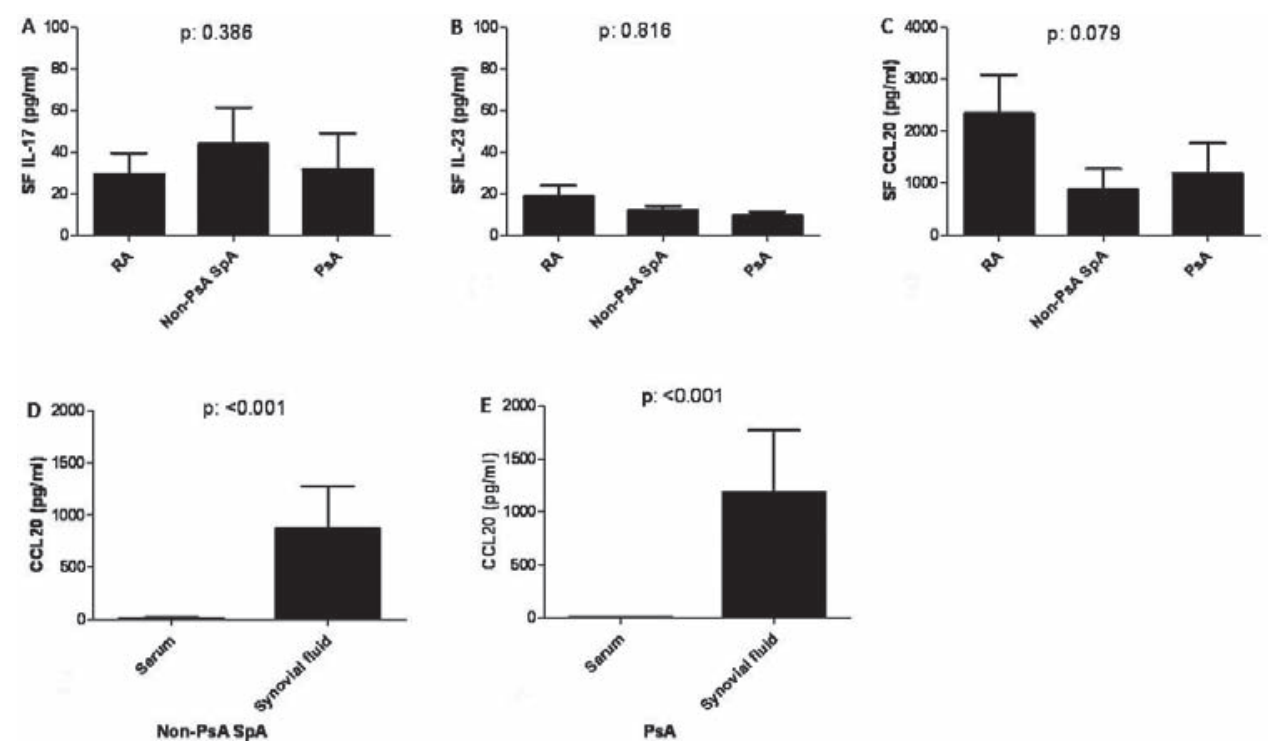

Figure 1 (A) IL-17, (B) IL-23 and (C) CCL20 were measured by sandwich ELISA in the syniovial fluid (SF) of 22 rheumatoid arthritis, 30 non-psoriatic arthritis (PsA) spondyloarthritis (SpA) and 22 PsA patients of the first study population. The CCL20 results in the paired serum samples of these (D) 30 non-PsA SpA and (E) 22 PsA patients are also depicted. The bars represent means \pm SEM

\section{Serum IL-23 levels strongly correlate with disease activity in RA}

In serum, we detected similar levels of IL-17 and CCL20 in HC, RA, PsA and non-PsA SpA patients $(p=0.358$ and $p=0.143$, respectively).
Overall, the interpatient variability of the serum IL-17 and serum CCL20 concentration was rather large and in the majority of the patient sera IL-17 and CCL20 levels were either very close to or below the detection limit of the assay. Also no significant differences $(p=0.320)$ were observed for serum 
IL-23 levels between the cohorts, although these levels tended to be slightly higher in RA patients (mean $50.92 \mathrm{pg} / \mathrm{ml}$; SEM 19.25) compared with HC (mean 15.10 pg/ml; SEM 4.90), nonPsA SpA (mean 16.87 pg/ml; SEM 3.45) and PsA (mean 11.87 $\mathrm{pg} / \mathrm{ml}$; SEM 2.97) patients (figure 2). In line with a previous report, ${ }^{28}$ serum IL-17 levels in non-PsA SpA patients, as in RA and PsA patients, did not correlate with systemic parameters of disease activity. In contrast; serum IL-23 levels in RA, but not in non-PsA SpA and PsA, strongly correlated with swollen joint count ( $r$ 0.697; $p=0.004)$, ESR (0.665; $p=0.013$ ), serum CRP levels ( $\mathrm{r} 0.578 ; \mathrm{p}=0.030$ ) as well as with the disease activity in 28 joints (DAS28) score index ( $\mathrm{0}$ 0.627; $\mathrm{p}=0.039$ ). Serum CCL20 in spondyloarthritis, as in RA, did not correlate with systemic disease activity parameters (table 3 ).

\section{Serum CCL20, IL-17 and IL-23 are not influenced by TNF blockade in spondyloarthritis}

In order to explore further the potential link between inflammation and the IL-23/IL-17 cytokine system in spondyloarthritis we measured the serum concentration of CCL20, IL-17 and IL-23 before and after 12 weeks of TNF blockade by infliximab treatment in 15 patients (eight non-PsA SpA and seven PsA).

As expected, TNF blockade was effective in reducing systemic measures of inflammation in this additional patient cohort. CRP $(p<0.05)$, ESR $(p<0.001)$ and swollen joint count $(p<0.001)$ decreased significantly after 12 weeks of treatment $(p<0.05)$ (table 1 (B)). In contrast, TNF blockade did not significantly influence serum CCL20 ( $\Delta$ mean $-2.12 \mathrm{pg} / \mathrm{ml}$; SSEM 1.93; $\mathrm{p}=0.307$ ), serum IL-17 ( $\Delta$ mean -1.56 pg/ml; $\triangle$ SEM 5.07; $\mathrm{p}=1.000)$ or serum IL-23 ( $\Delta$ mean $-0.75 \mathrm{pg} / \mathrm{ml}$; $\triangle$ SEM 4.65; p: 0.955) (figure 2). Also when non-PsA SpA and PsA patients were analysed separately we found no significant influence of infliximab treatment on serum CCL20, IL-17 and IL-23 levels (data not shown).

To acknowledge that this TNF independence was not merely the result of instability of the cytokine serum levels over time, we also investigated serum samples of 10 spondyloarthritis patients (five non-PsA SpA and five PsA) before and after 12 weeks of placebo treatment (data not shown). The 12-week time period did not influence CCL20 ( $\Delta$ mean $-2.65 \mathrm{pg} / \mathrm{ml}$; $\triangle$ SEM 5.71; $\mathrm{p}=0.508)$, IL-17 ( $\Delta$ mean $-1.75 \mathrm{pg} / \mathrm{ml} ; \Delta$ SEM 16.68; $\mathrm{p}=0.686)$, and IL-23 ( $\Delta$ mean $-1.29 \mathrm{pg} / \mathrm{ml} ; \Delta$ SEM 10.84; $\mathrm{p}=0.575)$

Table 2 Correlation analysis of SF levels of indicated mediators and local parameters of joint inflammation for the first study population.

\begin{tabular}{|c|c|c|c|c|c|c|}
\hline & \multicolumn{2}{|l|}{ SF IL-17 } & \multicolumn{2}{|l|}{ SF IL-23 } & \multicolumn{2}{|c|}{ SF CCL20 } \\
\hline & $\mathbf{r}$ & p Value & $\mathbf{r}$ & p Value & $\mathbf{r}$ & p Value \\
\hline \multicolumn{7}{|l|}{ RA } \\
\hline SF PMN count (cells/mm²) & 0.278 & 0.211 & 0.189 & 0.400 & 0.489 & 0.021 \\
\hline Synovial tissue T-cell infiltration & 0.185 & 0.463 & 0.064 & 0.801 & 0.453 & 0.059 \\
\hline Synovial tissue intimal lining layer hyperplasia & 0.583 & 0.009 & 0.657 & 0.002 & 0.463 & 0.046 \\
\hline Synovial tissue global cellular infiltration & 0.039 & 0.873 & 0.267 & 0.269 & 0.607 & 0.006 \\
\hline \multicolumn{7}{|l|}{ Non-PsA SpA } \\
\hline SF PMN count (cells/mm²) & 0.209 & 0.351 & -0.211 & 0.346 & 0.654 & 0.001 \\
\hline Synovial tissue T-cell infiltration & 0.018 & 0.935 & 0.013 & 0.955 & 0.208 & 0.353 \\
\hline Synovial tissue intimal lining layer hyperplasia & -0.043 & 0.850 & 0.206 & 0.357 & 0.113 & 0.616 \\
\hline Synovial tissue global cellular infiltration & -0.121 & 0.592 & 0.153 & 0.498 & 0.032 & 0.888 \\
\hline \multicolumn{7}{|l|}{ PsA } \\
\hline SF PMN count (cells/mm²) & 0.435 & 0.081 & 0.070 & 0.790 & 0.639 & 0.006 \\
\hline Synovial tissue T-cell infiltration & -0.166 & 0.539 & 0.427 & 0.099 & -0.276 & 0.301 \\
\hline Synovial tissue intimal lining layer hyperplasia & 0.159 & 0.556 & 0.159 & 0.556 & -0.483 & 0.058 \\
\hline Synovial tissue global cellular infiltration & -0.027 & 0.921 & 0.117 & 0.667 & 0.061 & 0.821 \\
\hline
\end{tabular}

All correlations were calculated with the Spearman correlation coefficient test.

PMN, polymorphonuclear; PsA, psoriatic arthritis; RA, rheumatoid arthritis; SF, synovial fluid; SpA, spondyloarthritis.

Figure 2 (A) IL-17, (B) IL-23 and (C) CCL20 were measured by sandwich ELISA in the serum of 22 rheumatoid arthritis (RA), 30 non-psoriatic arthritis (PsA) spondyloarthritis (SpA) and 22 PsA patients of the first study population and eight healthy controls (HC). (D-F) The same mediators were also measured in the serum before and after 12 weeks of TNF blockade in 15 spondyloarthritis patients (eight with non-PsA SpA and seven with PsA). The bars represent means \pm SEM.
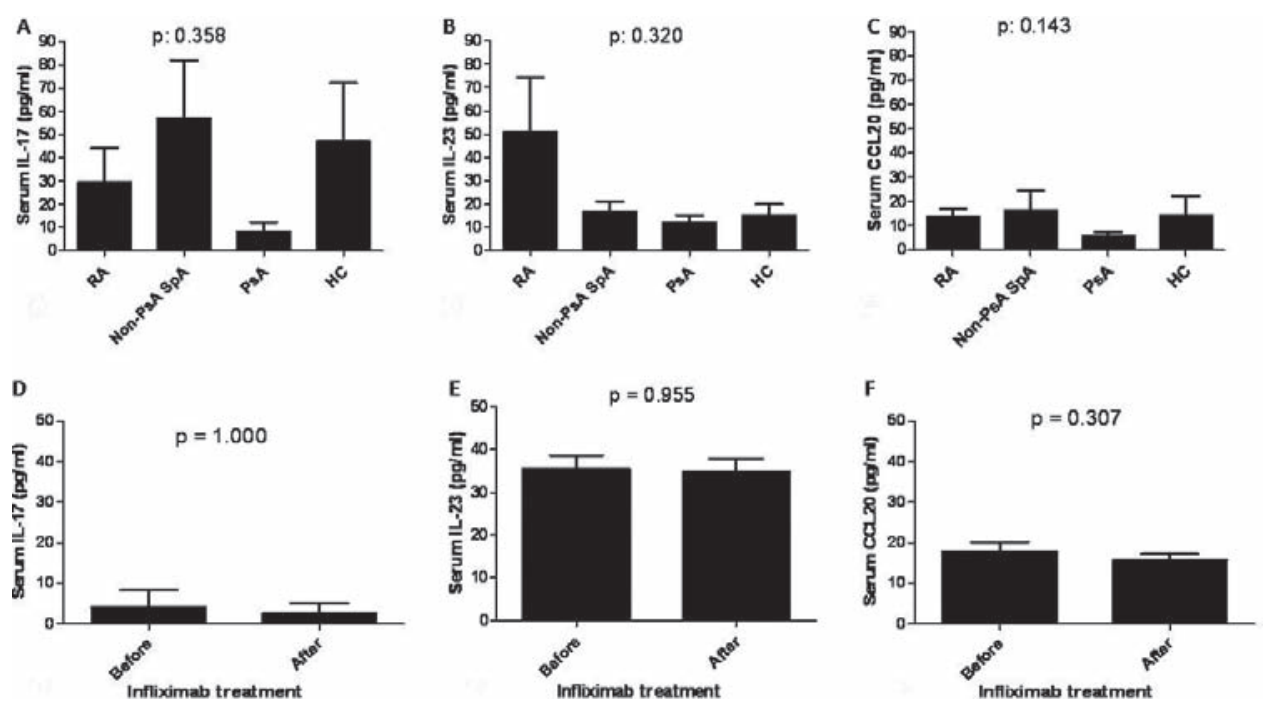
Table 3 Correlation analysis of serum levels of indicated mediators and systemic parameters of disease activity for the first population

\begin{tabular}{|c|c|c|c|c|c|c|}
\hline & \multicolumn{2}{|c|}{ Serum IL-17 } & \multicolumn{2}{|c|}{ Serum IL-23 } & \multicolumn{2}{|c|}{ Serum CCL20 } \\
\hline & $\mathbf{r}$ & p Value & $\mathbf{r}$ & p Value & $\mathbf{r}$ & p Value \\
\hline \multicolumn{7}{|l|}{ RA } \\
\hline SJC & -0.224 & 0.388 & 0.697 & 0.004 & 0.057 & 0.829 \\
\hline ESR & -0.041 & 0.884 & 0.665 & 0.013 & 0.432 & 0.108 \\
\hline CRP & 0.010 & 0.971 & 0.578 & 0.030 & 0.464 & 0.081 \\
\hline DAS28 & -0.262 & 0.388 & 0.627 & 0.039 & 0.126 & 0.681 \\
\hline \multicolumn{7}{|c|}{ Non-PsA SpA } \\
\hline SJC & -0.282 & 0.215 & -0.155 & 0.514 & -0.388 & 0.082 \\
\hline ESR & -0.228 & 0.334 & -0.001 & 0.997 & 0.139 & 0.558 \\
\hline CRP & -0.057 & 0.807 & -0.089 & 0.708 & 0.193 & 0.401 \\
\hline DAS28 & NA & NA & NA & NA & NA & NA \\
\hline \multicolumn{7}{|l|}{ PsA } \\
\hline SJC & 0.085 & 0.728 & 0.177 & 0.470 & 0.022 & 0.930 \\
\hline ESR & 0.267 & 0.284 & 0.009 & 0.972 & 0.212 & 0.398 \\
\hline CRP & 0.150 & 0.539 & -0.099 & 0.687 & 0.177 & 0.470 \\
\hline DAS28 & NA & NA & NA & NA & NA & NA \\
\hline
\end{tabular}

All correlations were calculated with the Spearman correlation coefficient test.

CRP, C-reactive protein; DAS28, disease activity score in 28 joints; ESR, erythrocyte sedimentation rate; NA, not assessed; PsA, psoriatic arthritis; RA, rheumatoid arthritis; SJC, swollen joint count; SpA, spondyloarthritis.

serum levels. Also when non-PsA SpA and PsA patients were analysed separately we found no significant influence of time on serum CCL20, IL-17 and IL-23 levels.

\section{DISCUSSION}

The IL-23/IL-17 axis has been shown to be a major proinflammatory pathway in several chronic inflammatory diseases. $^{6-8} 171822-24$

In this study we evaluated the relationship between the local and systemic expression of key mediators of this pathway and parameters of inflammation in spondyloarthritis patients.

A first finding of this study was that CCL20 levels strongly correlated with SF polymorphonuclear numbers in RA and spondyloarthritis. These data point towards a potentially important role for CCL20 as a mediator of joint inflammation in spondyloarthritis patients. CCL20 is produced locally in the joint by chondrocytes upon exposure to mechanical stress, ${ }^{29}$ by synovial fibroblasts upon stimulation with proinflammatory cytokines ${ }^{30}$ and by Th17 cells. ${ }^{31}$ CCL20 in turn, attracts immature myeloid dendritic cells ${ }^{32}$ as well as naive $B$ cells ${ }^{33}$ and effector memory $\mathrm{T}$ cells, especially Th17 cells. ${ }^{34}$

In addition, Ruth et $a^{\beta 5}$ showed that CCL20 accounts for approximately $40 \%$ of the chemotactic activity of the RA SF for monocytes. Also, blocking CCR6, the sole receptor for CCL20, protects mice from T-cell-mediated arthritis. ${ }^{10}$ In addition, serum CCL20 was not elevated in comparison with HC and was not modulated by TNF blockade in spondyloarthritis patients, which points towards a TNF $\alpha$ independent role for CCL20. Future studies will have to address the in-vivo role of the CCL20-CCR6 axis in the initiation and perseveration of inflammation in the joint, but also the gut, of spondyloarthritis patients.

In contrast to SF CCL20 in spondyloarthritis, SF IL-17 and IL-23 were not significantly increased compared with serum and did not correlate with local inflammatory parameters.

Another finding was that the degree of intimal lining layer hyperplasia in RA patients was strongly associated with IL-17, IL-23 and CCL20 levels in the joint.

Of note, also in the skin of psoriasis patients, Th17 responses are strongly correlated with epidermal hyperplasia. ${ }^{36} 37$
Intimal lining layer hyperplasia results from the accumulation of fibroblast-like as well as macrophage-like synoviocytes in the lining layer and is a common feature of chronic synovitis. ${ }^{38}$ IL-17 has been shown to activate fibroblast-like synoviocytes. ${ }^{39}$

Why the association between IL-23/IL-17 and lining hyperplasia was not present in spondyloarthritis patients, in whom lining layer hyperplasia was as pronounced as in the RA patients, is not clear at present.

The slightly elevated serum IL-23 levels in RA patients strongly correlated with disease activity parameters. In spondyloarthritis patients, by contrast, no correlations with CRP, ESR or swollen joint count were observed. IL-23 is a heterodimeric cytokine that is composed of an IL-12 p40 subunit together with an IL-23 p19 subunit, and is primarily produced by dendritic cells and monocytes. ${ }^{40}$ The production of the cytokine, which is dependent on the canonical nuclear factor $\kappa \mathrm{B}$ signalling pathway, ${ }^{41}$ is promoted by several factors including the triggering of innate immune receptors such as Toll-like receptor, ${ }^{40}$ dectin- $1^{42}$ or nucleotide oligomerisation domain 2 triggering ${ }^{43}$ as well as by the CD40 ligand. ${ }^{40}$ In line with the inflammatory nature of this cytokine, serum IL-23 levels in RA patients are decreased after TNF blockade. ${ }^{44}$ These observations suggest that IL-23 could be a valuable inflammatory biomarker in RA. This decrease after TNF blockade was not observed in our spondyloarthritis patient cohort treated with infliximab.

On the other hand, we found a trend towards slightly higher concentrations of IL-17 in the SF in non-PsA SpA patients compared with RA and PsA patients.

In conclusion, our data point towards a potentially important role for the Th17 cytokine system in joint inflammation and remodelling in chronic arthritis.

Furthermore, we found that the regulation of the Th17 cytokine system may be different between RA and spondyloarthritis synovitis. Indeed, a series of recent reports found a strong association between polymorphisms in the IL-23 receptor and the occurrence of spondyloarthritis ${ }^{2-4}$ as well as other, spondyloarthritis-related, seronegative chronic inflammatory diseases, ${ }^{13} 14$ but not of RA. ${ }^{45}$ These results warrant further 
investigation into this cytokine system as a potential therapeutic target in chronic arthritis.

Funding This study was supported by a concerted action grant of the Ghent University (GOA), grants from the Research Foundation Flanders (FWO-Vlaanderen) and a grant from Centocor Inc. Bernard Vandooren and Peggy Jacques are research assistants of the Research Foundation-Flanders (FWO-Vlaanderen).

\section{Competing interests None.}

Ethics approval This study was conducted with the approval of the Ethics Committee of the Ghent University Hospital.

Patient consent Obtained.

\section{REFERENCES}

1. Breban M. Genetics of spondyloarthritis. Best Pract Res Clin Rheumatol 2006;20:593-9

2. Burton PR, Clayton DG, Cardon LR, et al. Association scan of 14,500 nonsynonymous SNPs in four diseases identifies autoimmunity variants. Nat Genet 2007;39:1329-37.

3. Weaver CT, Hatton RD, Mangan PR, et al. IL-17 family cytokines and the expanding diversity of effector T cell lineages. Annu Rev Immunol 2007;25:821-52.

4. Murphy CA, Langrish CL, Chen Y, et al. Divergent pro- and antiinflammatory roles for IL-23 and IL-12 in joint autoimmune inflammation. J Exp Med 2003;198:1951-7.

5. Yen D, Cheung J, Scheerens H, et al. IL-23 is essential for T cell-mediated colitis and promotes inflammation via IL-17 and IL-6. J Clin Invest 2006;116:1310-16.

6. Amadi-Obi A, Yu CR, Liu X, et al. TH17 cells contribute to uveitis and scleritis and are expanded by IL-2 and inhibited by IL-27/STAT1. Nat Med 2007;13:711-18.

7. Aggarwal S, Ghilardi N, Xie MH, et al. Interleukin-23 promotes a distinct CD4 T cell activation state characterized by the production of interleukin-17. J Biol Chem 2003;278:1910-14.

8. Acosta-Rodriguez EV, Rivino L, Geginat J, et al. Surface phenotype and antigenic specificity of human interleukin 17-producing T helper memory cells. Nat Immunol 2007;8:639-46.

9. Baba M, Imai T, Nishimura M, et al. Identification of CCR6, the specific receptor for a novel lymphocyte-directed CC chemokine LARC. J Biol Chem 1997;272:14893-8.

10. Hirota K, Yoshitomi H, Hashimoto M, et al. Preferential recruitment of CCR6expressing Th17 cells to inflamed joints via CCL20 in rheumatoid arthritis and its animal model. J Exp Med 2007;204:2803-12.

11. Duerr RH, Taylor KD, Brant SR, et al. A genome-wide association study identifies IL23R as an inflammatory bowel disease gene. Science 2006;314:1461-3.

12. Cargill M, Schrodi SJ, Chang M, et al. A large-scale genetic association study confirms IL12B and leads to the identification of IL23R as psoriasis-risk genes. Am J Hum Genet 2007;80:273-90.

13. Annunziato F, Cosmi L, Santarlasci V, et al. Phenotypic and functional features of human Th17 cells. J Exp Med 2007;204:1849-61.

14. Wilson NJ, Boniface K, Chan JR, et al. Development, cytokine profile and function of human interleukin 17-producing helper T cells. Nat Immunol 2007;8:950-7.

15. Mannon PJ, Fuss IJ, Mayer L, et al.; Anti-IL-12 Crohn's Disease Study Group. Antiinterleukin-12 antibody for active Crohn's disease. N Engl J Med 2004;351:2069-79.

16. Krueger GG, Langley RG, Leonardi C, et al. A human interleukin-12/23 monoclonal antibody for the treatment of psoriasis. N Engl J Med 2007;356:580-92.

17. Dougados M, van der Linden S, Juhlin R, et al. The European Spondylarthropathy Study Group preliminary criteria for the classification of spondylarthropathy. Arthritis Rheum 1991;34:1218-27.

18. Arnett FC, Edworthy SM, Bloch DA, et al. The American Rheumatism Association 1987 revised criteria for the classification of rheumatoid arthritis. Arthritis Rheum 1988;31:315-24.

19. Taylor W, Gladman D, Helliwell P, et al. Classification criteria for psoriatic arthritis: development of new criteria from a large international study. Arthritis Rheum 2006;54:2665-73.

20. Baeten D, Van den Bosch F, Elewaut D, et al. Needle arthroscopy of the knee with synovial biopsy sampling: technical experience in 150 patients. Clin Rheumatol 1999;18:434-41.

21. Vandooren B, Kruithof E, Yu DT, et al. Involvement of matrix metalloproteinases and their inhibitors in peripheral synovitis and down-regulation by tumor necrosis factor alpha blockade in spondylarthropathy. Arthritis Rheum 2004;50:2942-53.
22. Koenders MI, Lubberts E, Oppers-Walgreen B, et al. Blocking of interleukin-17 during reactivation of experimental arthritis prevents joint inflammation and bone erosion by decreasing RANKL and interleukin-1. Am J Pathol 2005;167:141-9.

23. Koenders MI, Lubberts E, van de Loo FA, et al. Interleukin-17 acts independently of TNF-alpha under arthritic conditions. J Immunol 2006;176:6262-9.

24. Lubberts $\mathbf{E}$, Joosten LA, Oppers B, et al. IL-1-independent role of IL-17 in synovial inflammation and joint destruction during collagen-induced arthritis. J Immunol 2001; 167:1004-13.

25. Ferretti S, Bonneau 0, Dubois GR, et al. IL-17, produced by lymphocytes and neutrophils, is necessary for lipopolysaccharide-induced airway neutrophilia: IL-15 as a possible trigger. J Immunol 2003;170:2106-12.

26. Laan M, Cui ZH, Hoshino H, et al. Neutrophil recruitment by human IL-17 via C-X-C chemokine release in the airways. J Immunol 1999;162:2347-52.

27. Ye $\mathbf{P}$, Rodriguez FH, Kanaly S, et al. Requirement of interleukin 17 receptor signaling for lung CXC chemokine and granulocyte colony-stimulating factor expression, neutrophil recruitment, and host defense. J Exp Med 2001;194:519-27.

28. Wendling D, Cedoz JP, Racadot E, et al. Serum IL-17, BMP-7, and bone turnover markers in patients with ankylosing spondylitis. Joint Bone Spine 2007;74:304-5.

29. Haudenschild DR, Nguyen B, Chen J, et al. Rho kinase-dependent CCL20 induced by dynamic compression of human chondrocytes. Arthritis Rheum 2008:58:2735-42

30. Matsui T, Akahoshi T, Namai R, et al. Selective recruitment of CCR6-expressing cells by increased production of MIP-3 alpha in rheumatoid arthritis. Clin Exp Immunol 2001;125:155-61.

31. Pène J, Chevalier $S$, Preisser $L$, et al. Chronically inflamed human tissues are infiltrated by highly differentiated Th17 lymphocytes. J Immunol 2008;180:7423-30.

32. Dieu MC, Vanbervliet B, Vicari A, et al. Selective recruitment of immature and mature dendritic cells by distinct chemokines expressed in different anatomic sites. J Exp Med 1998;188:373-86.

33. Krzysiek R, Lefevre EA, Bernard J, et al. Regulation of CCR6 chemokine receptor expression and responsiveness to macrophage inflammatory protein-3alpha/CCL20 in human B cells. Blood 2000;96:2338-45.

34. Nistala K, Moncrieffe H, Newton KR, et al. Interleukin-17-producing T cells are enriched in the joints of children with arthritis, but have a reciprocal relationship to regulatory T cell numbers. Arthritis Rheum 2008;58:875-87.

35. Ruth JH, Shahrara S, Park CC, et al. Role of macrophage inflammatory protein-3alpha and its ligand CCR6 in rheumatoid arthritis. Lab Invest 2003;83:579-88.

36. Zaba LC, Cardinale I, Gilleaudeau P, et al. Amelioration of epidermal hyperplasia by TNF inhibition is associated with reduced Th17 responses. J Exp Med 2007;204:3183-94.

37. Zheng Y, Danilenko DM, Valdez P, et al. Interleukin-22, a T(H)17 cytokine, mediates IL-23-induced dermal inflammation and acanthosis. Nature 2007;445:648-51.

38. Goldenberg DL, Cohen AS. Synovial membrane histopathology in the differential diagnosis of rheumatoid arthritis, gout, pseudogout, systemic lupus erythematosus, infectious arthritis and degenerative joint disease. Medicine (Baltimore) 1978;57:239-52.

39. Chabaud M, Fossiez F, Taupin JL, et al. Enhancing effect of IL-17 on IL-1-induced IL-6 and leukemia inhibitory factor production by rheumatoid arthritis synoviocytes and its regulation by Th2 cytokines. J Immunol 1998;161:409-14.

40. Oppmann B, Lesley R, Blom B, et al. Novel p19 protein engages IL-12p40 to form a cytokine, IL-23, with biological activities similar as well as distinct from IL-12. Immunity 2000;13:715-25.

41. Mise-Omata S, Kuroda E, Niikura J, et al. A proximal kappaB site in the IL-23 p19 promoter is responsible for RelA- and c-Rel-dependent transcription. J Immunol 2007;179:6596-603.

42. LeibundGut-Landmann S, Gross 0, Robinson MJ, et al. Syk- and CARD9-dependent coupling of innate immunity to the induction of $\mathrm{T}$ helper cells that produce interleukin 17. Nat Immunol 2007;8:630-8.

43. van Beelen AJ, Zelinkova Z, Taanman-Kueter EW, et al. Stimulation of the intracellular bacterial sensor NOD2 programs dendritic cells to promote interleukin-17 production in human memory T cells. Immunity 2007;27:660-9.

44. Kageyama $\mathbf{Y}$, Ichikawa T, Nagafusa T, et al. Etanercept reduces the serum levels of interleukin-23 and macrophage inflammatory protein-3 alpha in patients with rheumatoid arthritis. Rheumatol Int 2007;28:137-43.

45. Wellcome Trust Case Control Consortium. Genome-wide association study of 14,000 cases of seven common diseases and 3,000 shared controls. Nature 2007;447:661-78. 